\title{
ONSITE GRAYWATER RECLAMATION TOWARDS ALLEVIATING WATER SHORTAGES AT THE HOUSEHOLD LEVEL
}

\author{
MAJDI ABOU NAJM, HISHAM HASAN, IBRAHIM ALAMEDDINE \& MUTASEM EL-FADEL \\ Department of Civil and Environmental Engineering, Faculty of Engineering and Architecture, \\ American University of Beirut, Lebanon
}

\begin{abstract}
Population growth and development, coupled with potential climate change impacts, are invariably associated with chronic water shortages particularly in arid and semi-arid regions. In this study, we evaluate the potential of using onsite graywater reclamation systems towards alleviating water shortages. For this purpose, we developed and administered a field questionnaire to assess the socioeconomic feasibility and public willingness towards the installation of such systems at the household level. Overall, $66 \%$ of the surveyed population approved of graywater reuse as compared to $48 \%$ who reported willingness to reuse wastewater. The results showed that acceptance of graywater reuse was a function of environmental awareness, household ownership, the age of the respondent, and access to alternative water sources. While graywater reuse can reduce water demand, its economic viability was found to be contingent on reforming the existing public water tariff structure. Under existing water use rates, the payback period for retrofitting a residence with a graywater reclamation system exceeded 30 years but went down to 9-12 years after accounting for water procurement from outside the network. The study concludes with a SWOT analysis and a management framework to integrate graywater reclamation as a source of water to supplement existing sources and help alleviate water shortages.
\end{abstract}

Keywords: graywater, water reuse, urban water, water shortage, graywater reclamation.

\section{INTRODUCTION}

A wide range of water management strategies evolved in response to increasing global water shortages. Such strategies either focused on increasing water supplies or decreasing water demands. Traditional supply methods include sea water desalination [1], [2] or further exploitation of already stressed surface and ground water sources. Such exploitation has reduced available renewable sources and increased their vulnerability to saltwater intrusion, particularly in coastal urban areas [3], [4]. On the other hand, demand management methods aim to reduce water demand through the efficient use and reuse of water resources. Water reuse is dependent on the level of treatment and covers a wide range of applications [5] from agriculture and landscape irrigation, domestic usage in toilet flushing [6]-[9], use in groundwater recharge [10]-[12], and/or mixing with construction material [13], [14].

Wastewater reuse has the double advantage of reducing the pressure on water resource exploitation, and minimizing wastewater discharge. Municipal wastewater can be divided into two main types namely blackwater and graywater [5], [15]. Graywater is the water draining from household sinks, showers, and laundry. While kitchen water is often considered part of graywater, it is not recommended for household reuse because it contains large amounts of bacteria, fat, oil and grease [16], [17]. On the other hand, blackwater is the remaining wastewater that contains human wastes and is thus characterized by even higher contaminant levels [18], [19]. Therefore, more treatment is required for the reuse of regular wastewater as compared to graywater [5], [20], [21].

Graywater comprises a substantial amount (50 to 80\%) of total residential wastewater, with reported daily volumes ranging from 15-44 L/capita [9] up to 90-120 L/capita [22], 
rendering its onsite reuse a major relief to freshwater resources and wastewater treatment plants [17], [23]. Efficiencies may vary in accordance with consumption patterns, with reported savings reaching up to 50\% [6], [23], [24].

Economically, graywater reuse systems are typically attractive options with payback periods ranging between 2-14 years. The payback period is highly dependent on the local water tariff structure, building size, treatment type and end use [25], [26]. The feasibility of graywater reuse generally improves with growing awareness about water scarcity and the economic implications of environmental degradation, as well as the decreasing cost of treatment technologies [27].

In this study, we explore the potential of graywater reclamation in urban areas with water shortages, but where wastewater reuse is not widely acceptable by the public. For this purpose, the public perception of graywater reuse is assessed using a field questionnaire developed and administered at a pilot area. The collected data is analyzed statistically through binomial regression to identify patterns and factors that affect the approval and adoption of graywater reclamation.

\section{METHODS}

\subsection{Study area}

The study area comprises three rapidly urbanizing districts located southeast of Beirut, Lebanon (Fig. 1). They receive water from the Greater Beirut and Mount Lebanon Water Establishment. The water tariff structure is a traditional yearly lump sum fee that is independent of total water delivered or consumed.

Typically, water is supplied through an old and leaky distribution network leading to a staggering 40 to $50 \%$ of water loss [32]. Such losses, when coupled with limited availability, result in intermittent supplies all year round, even during the rainy season. In fact, water rationing in the dry season increases to a point where a large portion of the population resorts to purchasing of water (i.e. water tankers) to meet daily needs. Water purchase created locally unregulated economies making the delivery of water through water tankers a profitable business, and making water an expensive commodity for urban dwellers. Additionally, the source of water used by water tankers is usually unknown and is often thought to be of inferior quality.

Table 1: Reported payback period in previous studies.

\begin{tabular}{|llll|}
\hline Study & Treatment system & Location & $\begin{array}{l}\text { Payback period } \\
\text { (years) }\end{array}$ \\
\hline$[28]$ & Septic tank, aerated bioreactor, slow sand filter & United Kingdom & $\begin{array}{l}8-9 \text { (old bldg.) } \\
4-5 \text { (new bldg.) }\end{array}$ \\
{$[7]$} & Filtration, sedimentation, disinfection & Spain & 14 \\
{$[23]$} & Rotating biological contactors & Israel & $6.4-15$ \\
{$[29]$} & Filtration, sedimentation, aeration, disinfection & India & 2 \\
{$[30]$} & Constructed wetland & Syria & $3-7$ \\
{$[31]$} & Fixed bed reactor, UV & Brazil & 5 \\
\hline
\end{tabular}



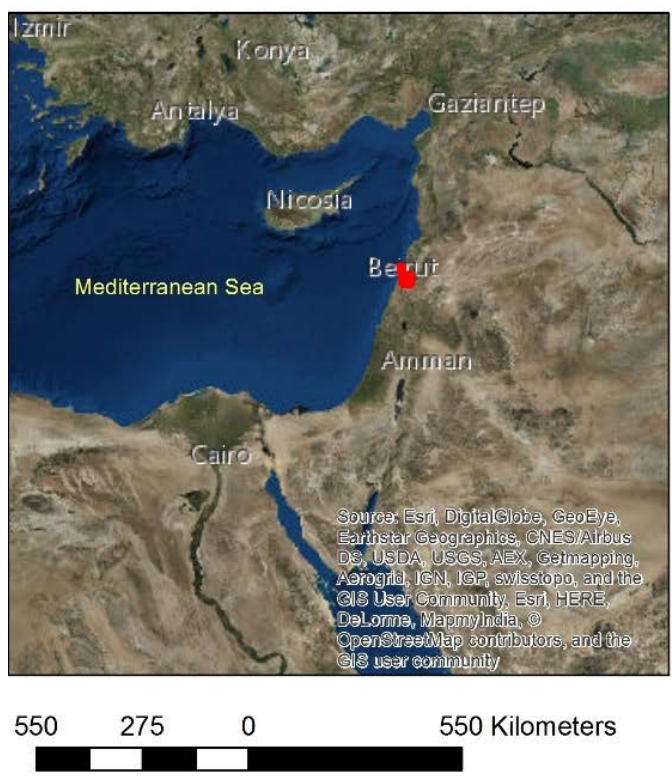

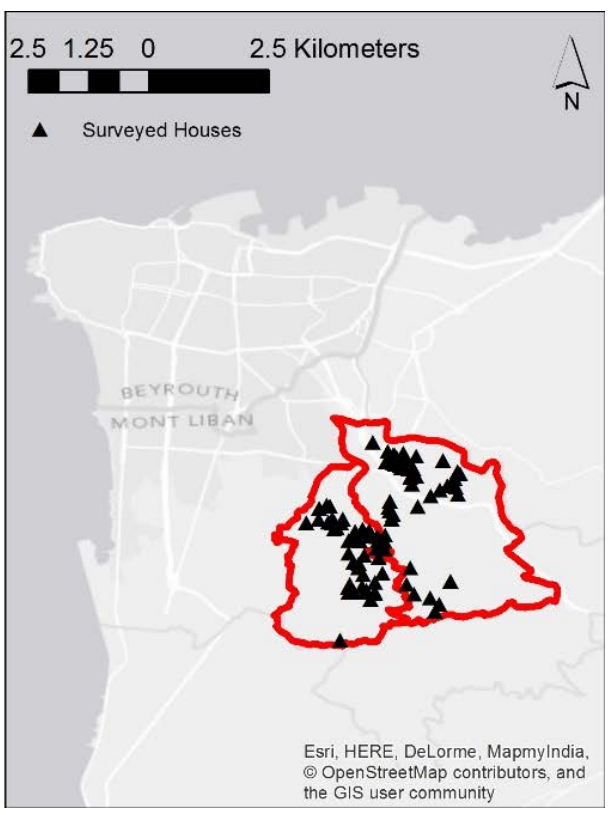

Figure 1: Location of the study area.

A cheaper and more abundant source of water is through groundwater extraction, but unsustainable practices led to chronic seawater intrusion problems along coastal cities, particularly Beirut. The situation is exacerbated by wastewater seepage into artesian wells at some locations, raising health concerns for residents relying on groundwater.

\subsection{Evaluation of public perception}

This study focuses on graywater reuse and people's openness towards adopting such a technology at the building or community scale in an urban setting. This was evaluated through a survey conducted via personal interviews during household visits. Those visits were on a one-household-per-building basis, with the surveyed buildings chosen randomly and scattered throughout the study area. The sample size included 103 households, representing approximately $0.4 \%$ of the total population of the study area. For the interviews, a questionnaire was developed which covered household socioeconomics, sources of water, quality and consumption patterns of supplied water, public perception of rainwater collection and graywater reclamation systems, and participants' willingness to implement such technologies.

Statistical analysis was used to study the factors influencing the acceptance of graywater reuse and the willingness to implement. This was conducted through the development of logistic regression, using the $\mathrm{R}$ statistical software, typically used when the predicted variable is binary in nature ( 0 or 1$)$. Three response variables were tested: (1) acceptance of graywater reuse; (2) willingness to implement graywater reclamation at the building and (3) willingness to implement at the community level in an urban setting. The first statistical model predicts the acceptance of graywater reuse within the surveyed sample. All predictors were tested by 
computing the statistical significance at the $90 \%$ level (alpha $=0.1)$. After determining the parameters that were individually influencing the variables of interest, stepwise regression was used to determine the optimal combination of parameters based on the Akaike Information Criterion (AIC). The odds ratio of each model's components are calculated and discussed. The pseudo- $\mathrm{R}^{2}$ value was used to better understand the percentage of data variability explained by the model.

\subsection{Economic assessment}

The cost of implementing graywater reuse can be divided into two parts: the retrofitting and the treatment system costs. Retrofitting is needed to allow for dual-plumbing needed to separate graywater from blackwater, and to supply the reuse water back to the toilets. Retrofitting costs were estimated for a typical sized apartment for an average family of 4 individuals. Treatment costs were divided into capital (procurement and installation) and operating and maintenance expenses.

Furthermore, an assessment of cost-effectiveness of graywater reclamation at the building level in the study area was conducted. The full implementation costs were compared to the potential water savings using current water rates, and a payback period was estimated using the net present value (NPV) concept (eqn (1)).

$$
N P V_{T}=\sum_{t}^{T} \frac{C_{T}}{(1+i)^{t}}-C_{0}
$$

where $\mathrm{C}_{\mathrm{T}}$ is the net savings per year, $\mathrm{C}_{0}$ the capital cost, and $i$ the inflation rate. Investment is returned when NPV $>0$.

\subsection{SWOT analysis}

A SWOT analysis was conducted to categorize the internal (in terms of strengths and weaknesses) and external (in terms of opportunities and threats) factors that potentially determine the viability of graywater reuse in urban setups and help devise management strategies to improve the chances of successful implementation. The study concludes with a proposed management framework that increases the viability of graywater reuse to improve urban water efficiency while ensuring correct and safe implementation. The framework includes amending/enacting a set of legislations, conducting awareness and capacity building campaigns, and establishing a monitoring and control scheme.

\section{RESULTS AND DISCUSSIONS}

A summary of buildings' characteristics is presented in Table 2 and further statistics about approval rates and willingness to implement are depicted in Fig. 2. The median values for the number of floors (4) and roof area $\left(300 \mathrm{~m}^{2}\right)$ were adopted for the retrofit case study, while other characteristics such as the annual water bill (average: 186.7 USD) and rate of reliance on water tankers $(49 \%)$ were considered in the economic analysis.

\subsection{Statistical analysis}

The three surveyed areas exhibited similar results with no noticeable differences. Approval rates varied between graywater acceptances as a concept to actual implementation (willingness to implement) at the building or community level (Fig. 2). 
Table 2: Study area characteristics.

\begin{tabular}{|llll|}
\hline \multicolumn{1}{l|}{ Characteristic } & Mean & Median & Standard deviation \\
\hline Number of floors & 4.6 & 4 & 1.3 \\
Age of building (years) & 34.4 & 35 & 20.4 \\
Roof area $\left(\mathrm{m}^{2}\right)$ & 338.6 & 300 & 121.4 \\
Annual water bill (USD) per household & 186.7 & 188.8 & 57.2 \\
Number of days water is supplied in the dry & 2.2 & 2 & 1.2 \\
season & & & \\
Hours of supply on water provision days of & 5.3 & 4 & 5.7 \\
the dry season & 2 & 2 & 0.6 \\
Number of storage tanks per household & 2 & 2 & 16.6 \\
Volume of main storage tank $\left(\mathrm{m}^{3}\right)$ & 9.3 & 2 & 15.4 \\
Age of household head & 57 & 60 & \\
\hline
\end{tabular}

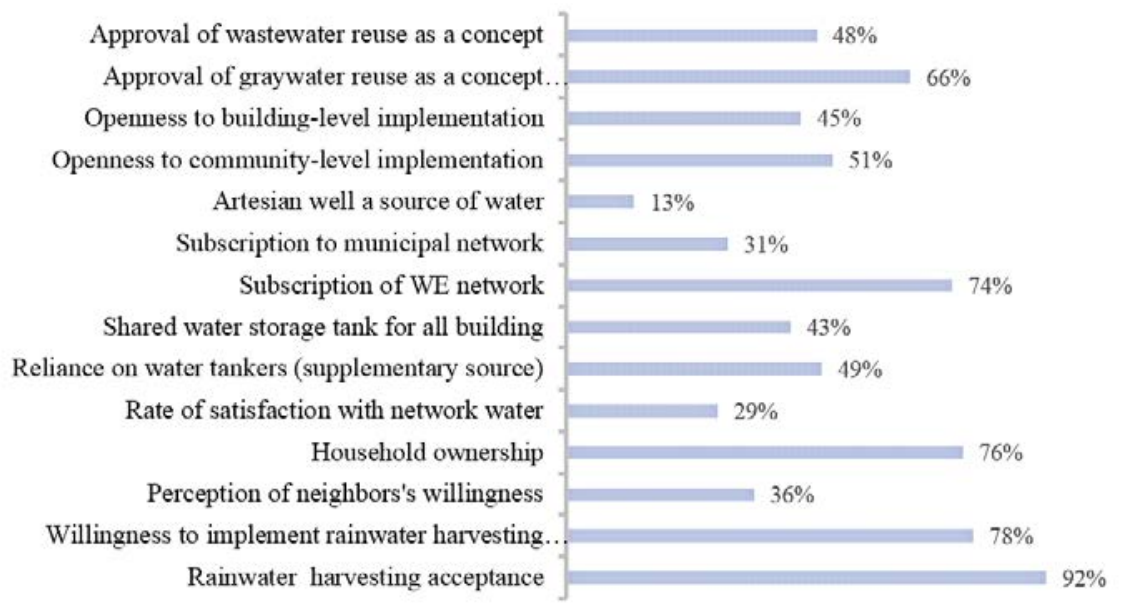

Figure 2: Socio-economic and water-related parameters in the study area.

\subsubsection{Graywater acceptance}

Survey results revealed that people's acceptance of rainwater harvesting influenced their acceptance of graywater reclamation positively ( $p$-value $=0.097)$. This is expected as both techniques provide new water sources and are both considered to be green initiatives. Household ownership ( $p$-value $=0.048$ ) was also found to be a factor affecting people's acceptance positively. Moreover, residents who previously renewed their apartment's piping ( $p$-value $=0.092)$ expressed increased acceptance to graywater reuse. Finally, the presence of an artesian well supplying the household provides a sense of water security, which could explain its negative influence on peoples' openness to resort to other sources such as reused water $(p$-value $=0.032)$. After performing a stepwise regression, the final model incorporated three variables as significant predictors for graywater acceptance (Table 3 ). 
Table 3: Results of the model that predicts graywater acceptance $(N=103)$.

\begin{tabular}{|c|c|c|c|}
\hline Variable & Odds ratio $^{\mathrm{a}}$ & $90 \%$ conf. int. for odds ratio ${ }^{b}$ & $P$-value \\
\hline Intercept & 2.544 & $1.525-4.403$ & 0.004 \\
\hline Rejecting rainwater harvesting & 0.180 & $0.079-0.582$ & 0.079 \\
\hline Renting the household & 0.221 & $0.032-0.884$ & 0.012 \\
\hline $\begin{array}{l}\text { Number of times municipal water } \\
\text { is supplied per week in winter }\end{array}$ & 1.449 & $1.144-1.896$ & 0.015 \\
\hline
\end{tabular}

${ }^{a}$ The effect of the variable on the chance of accepting graywater reuse.

${ }^{\mathrm{b}}$ The range of the odds ratio within a $90 \%$ confidence interval.

The logistic regression model indicates that graywater acceptance is significantly affected by rainwater harvesting acceptance, ownership of residence and supply frequency of water in the winter. The odds ratio suggests that there is a 2.54 to $1(72 \%)$ chance of accepting graywater reuse by an individual that has a favorable view of rainwater harvesting, owns the residence, and has a twice per week water supply frequency in winter. Meanwhile, those who accept rainwater harvesting are 5.5 times more likely to accept graywater reuse as compared to those that disapproved of rainwater harvesting. Moreover, compared to rental, household ownership increases the odds of accepting graywater reuse by 4.5 times. Finally with every day increase in the frequency of water supply in the winter, the respondents' odds of accepting graywater reuse increases by $45 \%$. The maximum computed pseudo- $\mathrm{R}^{2}$ for this logistic model obtained through Cragg and Uhler's method is 0.406 , meaning that the model explains about $41 \%$ of the variability in the data.

\subsubsection{Implementation at building level}

To predict the willingness to implement graywater reuse at the building scale, analysis was limited to respondents who had a favorable view of graywater reuse (64 out of 103 surveyed) as it was presumed that those who had an unfavorable view for the concept of reusing graywater would not answer positively to the possibility of sharing a graywater reuse system. According to the results, larger yearly water bills decreased the willingness of adopting graywater reuse at the building level $(p$-value $=0.024)$, which indicates that respondents saw the technology as an added financial burden rather than a chance to save on water consumption. Moreover, the willingness was reduced when the number ( $p$-value $=0.096$ ) or volume ( $p$-value $=0.077$ ) of household storage tanks increased; this could be linked to the fact that storing a large quantity of water reduces the chances of facing water shortages. Finally, residents were more willing to adopt graywater reuse when they believed that their building neighbors would agree to contribute to such a plan $(p$-value $=0.032$ ). The final model explaining the willingness to implement graywater reuse at the building level is shown in Table 5 and it includes only one significant predictor which is the perception of neighbors' openness to participate in a graywater reuse plan at the building-scale. According to the model, when respondents believe that the neighbors would welcome the implementation of a graywater reuse plan at their building, the chances of adopting graywater reuse at the building level are 4 to 1 , and is approximately 6 times (more likely as compared to a situation where the building neighbors are not perceived to be willing to adopt the technology. Note that the model received a maximum pseudo- $\mathrm{R}^{2}$ of 0.715 (Table 4 ). 
Table 4: Pseudo- $\mathrm{R}^{2}$ results of all logistic models of this study.

\begin{tabular}{|llll|}
\hline Model & $\begin{array}{l}\text { McFadden's } \\
\text { method }\end{array}$ & $\begin{array}{l}\text { Maximum likelihood } \\
\text { method }\end{array}$ & $\begin{array}{l}\text { Cragg and Uhler's } \\
\text { method }\end{array}$ \\
\hline Graywater acceptance & 0.255 & 0.312 & 0.406 \\
Building-level implementation & 0.458 & 0.636 & 0.715 \\
Community-level implementation & 0.401 & 0.434 & 0.573 \\
\hline
\end{tabular}

Table 5: Model for predicting willingness to implement graywater reuse at building scale.

\begin{tabular}{|llll|}
\hline Variable & Odds ratio & $\begin{array}{l}90 \% \text { conf. int. for } \\
\text { odds ratio }\end{array}$ & $P$-value \\
\hline $\begin{array}{l}\text { Intercept } \\
\begin{array}{l}\text { Building residents are thought to be unwilling } \\
\text { to implement graywater reuse at their building }\end{array}\end{array}$ & 0.1600 & $1.510-13.355$ & 0.032 \\
\hline
\end{tabular}

\subsubsection{Implementation at community level}

For interventions at the community scale, three significant predictors were determined: the approval to participate in a rainwater harvesting plan at the community level ( $p$-value $=0.008)$, the willingness to implement a graywater reuse plan at the building level $(p$-value $=0.02)$, and the age of household head, with younger respondents displaying more openness towards the adoption of a community level graywater reclamation systems ( $p$-value $=0.094)$ as compared to older individuals. This is an interesting outcome, which could imply that the younger population is more environmentally friendly and aware of the scientific advances, and is thus more receptive to relatively-modern technologies for the reduction of water consumption.

Table 6 shows the resulting model that predicts the willingness to implement graywater reuse at the community level. The model has two significant predictors. Under a baseline condition consisting of approving both plans, the odds of implementing a graywater reclamation at the community level are 10.4 to 1 . Furthermore, the willingness to implement rainwater harvesting at the community level increases the chance of adopting communitylevel graywater reuse by 67 times. Similarly, the willingness to implement at building level increases the willingness to implement at the community level by approximately 13 times. The model had a maximum pseudo- $\mathrm{R}^{2}$ of 0.573 (Table 4). The value is remarkably lower than the earlier model that predicted the willingness to implement graywater reuse at the building level, despite having two significant predictors.

\subsection{Economic analysis}

To assess the cost-effectiveness of adopting graywater reuse at the building level in the study area, the saved water cost needs to be compared to the capital and operating costs associated with building-level implementation. The total estimated capital costs for the implementation of the system for the building, including retrofitting and treatment system costs, were estimated at 10,300 USD, leading to an estimate of 1300 USD per household in a typical building with 8 households. With respect to water cost, the volumetric water charge in the 
Table 6: Model predicting willingness to implement graywater reuse at community scale.

\begin{tabular}{|c|c|c|c|}
\hline Variable & Odds ratio & $\begin{array}{l}90 \% \text { conf. int. for } \\
\text { odds ratio }\end{array}$ & $P$-value \\
\hline Intercept & 10.40 & $3.636-45.48$ & 0.002 \\
\hline $\begin{array}{l}\text { Disapproval of participating in a } \\
\text { municipal rainwater harvesting plan }\end{array}$ & 0.015 & $0.001-0.089$ & 0.001 \\
\hline $\begin{array}{l}\text { Disapproval of graywater reuse at } \\
\text { building level }\end{array}$ & 0.078 & $0.015-0.281$ & 0.003 \\
\hline
\end{tabular}

study area is $0.43 \mathrm{USD} / \mathrm{m}^{3}$ and the daily water consumption per capita is estimated at 180 liters [32]. Assuming 4 individuals per household (from the survey), the estimated yearly consumption would amount to $263 \mathrm{~m}^{3}$. Meanwhile, the adoption of graywater reuse for toilet flushing is expected to save $79 \mathrm{~m}^{3}$ of household consumption. At the current rate, the yearly savings per household would amount to around $\$ 34$, meaning that the payback period for the retrofitting costs alone would exceed 30 years.

However, considering the water shortages and rationing policy in the study area, a large portion of the population relies on water tankers in the dry season, as a supplementary water source (about $49 \%$ of surveyed households) [33]. Accounting for expenditure on water tankers can result in a more realistic payback period which is considerably shorter since the median monthly expenditure on water tankers according to the survey results is 147 USD. Assuming the water shortage occurs for 3 or 4 months in the dry season of every year, the resulting yearly water tanker expenses per household would be 440 or 586 USD, respectively. If $30 \%$ of that is also saved by adopting graywater reuse, and added to original metered water savings, then the payback period is reduced to 9-12 years of adopting graywater reuse at an inflation rate of $5 \%$ (Fig. 3).

The current water tariff structure in the study area is acknowledged to be far from ideal since the largest portion of subscribers pay a flat lump sum tariff irrespective of actual consumption, due to the absence of water meters, and there remains no wastewater tariffs to date [32]. Therefore, the installation of meters for all subscribers would be an essential first step that provides more accurate insight into water consumption patterns and help devise a convenient water tariff structure that maintains affordability while promoting water conservation and reuse. In the same context, the establishment of a wastewater tariff would also deliver an added incentive to increase the feasibility of adopting graywater reuse.

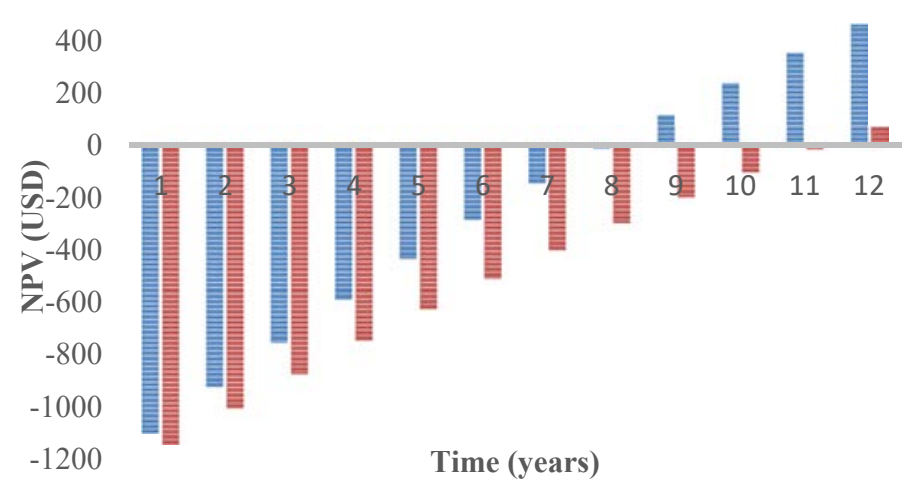

Figure 3: Cumulative NPV if water tankers are needed for 3 (orange) or 4 months (blue). 


\subsection{SWOT analysis}

The SWOT analysis aimed at categorizing the internal and external factors affecting graywater reuse, and needed for devising a management plan for implementation in urban setups. Table 7 summarizes the strengths, weaknesses, opportunities and threats associated with the adoption of graywater reuse, particularly in the local context.

\subsection{Management framework}

Graywater reuse should be adopted as part of a set of alternative water sources constituting a sustainable water management framework. This becomes most effective if a policy controlling the exploitation of vulnerable sources, particularly groundwater, can be enforced to regulate the supply and entice residents to adopt the use of water conservation and reuse methods. Several institutions would take part in the development and implementation of such a management framework. The roles of those institutions are presented in Table 8. For example, the legislative bodies are required to set up the necessary regulations after reviewing international legislations and conducting necessary research while local authorities would be responsible to ensure compliance with proposed regulations through direct contact with consumers. In parallel, media and civil society would play a major role through awareness campaigns about water scarcity and efficient water management techniques such as graywater reuse to increase public recognition and acceptance of reuse systems. Finally, approaching the issue of adopting graywater reuse at the governance level requires careful distinction in the implementation at an existing building as compared to new buildings.

Table 7: SWOT analysis.

\begin{tabular}{|c|c|}
\hline Strengths & Weaknesses \\
\hline $\begin{array}{l}\text { - } \quad \text { Reliable all-year-round source of water } \\
\text { - Treating graywater for reuse in landscape irrigation } \\
\text { and toilet flushing reduces demand on freshwater } \\
\text { sources } \\
\text { - Adopting a decentralized reuse scheme with minimal } \\
\text { institutional involvement } \\
\text { - Simple technology managed by its users } \\
\text { - Demand reduction positively impacts government } \\
\text { - } \quad \text { Promonditures on water sources }\end{array}$ & $\begin{array}{l}\text { - Traditional plumbing does not separate } \\
\text { graywater from blackwater drainage } \\
\text { - } \quad \text { Retrofit is often expensive and } \\
\text { inconvenient } \\
\text { - Additional capital costs required to install } \\
\text { a treatment system } \\
\text { Lack of public knowledge about the } \\
\text { importance of water conservation and } \\
\text { scarcity of resources } \\
\text { - Require allocation of some government } \\
\text { resources to monitor implementation }\end{array}$ \\
\hline Opportunities & Threats \\
\hline $\begin{array}{l}\text { - Recurrence of drought events are increasing local } \\
\text { governments acceptance to wastewater reuse } \\
\text { Demand reduction reduces groundwater } \\
\text { overexploitation, thus saltwater intrusion } \\
\text { - } \quad \begin{array}{l}\text { Return on investment can be less than } 10 \text { years in } \\
\text { some cases }\end{array} \\
\text { - Introducing a new plumbing code can eliminate the } \\
\text { cost of retrofit (around } 50 \% \text { of the capital cost here) } \\
\text { - Installation of water meters and charging by volume } \\
\text { present additional incentives } \\
\text { Awareness/educational campaigns about water } \\
\text { scarcity and potential efficiency of wastewater reuse } \\
\text { can significantly improve acceptance rates }\end{array}$ & $\begin{array}{l}\text { - General public skepticism about } \\
\text { wastewater reuse and efficiency of } \\
\text { treatment technologies } \\
\text { - } \quad \text { Risk of mismanagement and use for } \\
\text { unintended purposes } \\
\text { - Potential health risks in case of cross- } \\
\text { contamination between graywater and } \\
\text { potable water networks } \\
\text { - Requires regular maintenance to ensure } \\
\text { treatment efficiency } \\
\text { - Current lack of local regulations/ } \\
\text { standards for quality of water intended for } \\
\text { domestic reuse }\end{array}$ \\
\hline
\end{tabular}


Table 8: Institutional framework for graywater reuse.

\begin{tabular}{|c|c|}
\hline Institution & Responsibilities \\
\hline $\begin{array}{l}\text { Water } \\
\text { establishment }\end{array}$ & $\begin{array}{l}\text { - Implementation of water metering (currently at } 10 \% \text { ) } \\
\text { - } \\
\text { - } \text { Montablish increasing tariff structure to encourage conservative usage } \\
\text { - } \\
\text { Preverce compliance through taxes further groundwater exploitation and start decommissioning illegal } \\
\text { wells }\end{array}$ \\
\hline $\begin{array}{l}\text { Ministry of } \\
\text { Energy and } \\
\text { Water }\end{array}$ & $\begin{array}{l}\text { - Establish water rights for building/community implementation } \\
\text { - Establish permit procedure for graywater reuse } \\
\text { - } \text { Fund a set of pilot graywater reuse projects at various locations and for } \\
\text { different applications, and report the successes and failures } \\
\text { - Provide subsidies for graywater reuse implementation through low interest } \\
\text { loans } \\
\text { - Tax exemptions on procurement of treatment systems (new and old buildings) } \\
\text { - Tax cuts on treatment consumables and graywater-friendly household } \\
\text { chemicals }\end{array}$ \\
\hline $\begin{array}{l}\text { Ministry of } \\
\text { Interior and } \\
\text { Municipalities }\end{array}$ & $\begin{array}{l}\text { - Establish municipal tax exemptions to graywater reuse adopters } \\
\text { - Study the potential for community-level graywater reuse projects }\end{array}$ \\
\hline $\begin{array}{l}\text { Ministry of } \\
\text { Public Health }\end{array}$ & $\begin{array}{l}\text { - Establish quality standards for graywater reuse depending on its intended end- } \\
\text { use to minimize potential health risks while maintaining feasibility }\end{array}$ \\
\hline $\begin{array}{l}\text { Order of } \\
\text { Engineers }\end{array}$ & $\begin{array}{l}\text { Modify building codes for mandatory segregation of graywater from } \\
\text { blackwater } \\
\text { - Establish retrofit guidelines for graywater reuse implementation (old } \\
\text { buildings) } \\
\text { - Form guidelines for graywater reuse including dual water supply lines, best } \\
\text { management practices, and treatment systems }\end{array}$ \\
\hline Civil Society & $\begin{array}{l}\text { - Awareness campaigns on scarcity and vulnerability of freshwater sources } \\
\text { - Introduce the concept of graywater (vs. blackwater) as a reliable year-round } \\
\text { alternative water source, and connect its applications to treatment level } \\
\text { - Inform the public about tax exemptions and benefits associated with graywater } \\
\text { reuse, and the existing guidelines for implementations at new and old } \\
\text { buildings } \\
\text { - Highlight the importance of using graywater-friendly chemicals to ensure } \\
\text { efficient treatment and prevent damage to soil (in the case of irrigation) }\end{array}$ \\
\hline Media & $\begin{array}{l}\text { - Increase campaigns about water scarcity and needed conservation measures } \\
\text { - Highlight graywater reuse and associated benefits in terms of tax cuts and } \\
\text { exemptions. } \\
\text { - Public awareness to best management practices to ensure safe and hygienic } \\
\text { graywater reuse }\end{array}$ \\
\hline
\end{tabular}

Any successful management framework for improved graywater reuse must target a change in water consumptive behaviors in terms of perception and quantities. As such, the water consumer is placed as its center point with four agents of change around: awareness, incentives, legislations, and taxations, with various institutions having roles to play in each of the different agents. 


\section{CONCLUSION}

Graywater reuse is a viable option to reduce potable water demand in urban communities suffering from chronic water shortages. This study explored the feasibility and the factors that affected the acceptability of graywater reuse in urban communities. The statistical analysis identified some patterns that need to be considered when devising a future water reuse management plan at the building and community scales. A subsequent economic analysis concluded that graywater reuse may not be economically attractive under the current water tariff structure in the pilot area, particularly with a payoff period exceeding 30 years. However, accounting for water shortages and the need in certain areas for procuring water through private water tankers in the dry season reduces the payoff period to 9-12 years. SWOT analysis and a comprehensive survey of involved stakeholders resulted in the establishment of a management framework which identifies the responsibilities of the various institutions, and highlights the needed steps for a successful graywater reuse plan. The current water billing configuration needs to be revised through an increasing tariff structure to encourage efficient water use. This requires installation of water meters for all subscribers; as compared to a current only $10 \%$, leaving the majority of subscribers discouraged or uninterested in efficient water use. Furthermore, groundwater exploitation must be regulated through stricter rules to limit the extent of saltwater intrusion. Finally, graywater reuse can be encouraged through the launching of awareness campaigns to educate the general public on the importance of water resources, saltwater intrusion, and water-efficient approaches including graywater reuse.

\section{ACKNOWLEDGEMENT}

The authors would like to acknowledge the support of the US Agency for International Development under the PEER initiative (grant number USAID-OAA-A-I1-00012).

\section{REFERENCES}

[1] Gleick, P.H., World's Water, Volume 8: Biennial Report on Freshwater Resources, Island Press: Washington, DC, 2014.

[2] Lattemann, S. \& Höpner, T., Environmental impact and impact assessment of seawater desalination. Desalination, 220, pp. 1-15, 2008.

[3] Barlow, P.M. \& Reichard, E.G., Saltwater intrusion in coastal regions of North America. Hydrogeology Journal, 18, pp. 247-260, 2010.

[4] Mahesha, A. \& Lakshmikant, P., Saltwater intrusion in coastal aquifers subjected to freshwater pumping. Journal of Hydrologic Engineering, 19, pp. 448-456, 2014.

[5] EPA, Guidelines for Water Reuse, US Environmental Protection Agency Office of Wastewater Management: Washington, DC, 2012.

[6] Campisano, A. \& Modica, C., Experimental investigation on water saving by the reuse of washbasin grey water for toilet flushing. Urban Water Journal, pp. 17-24, 2010.

[7] March, J.G., Gual, M. \& Orozco, F., Experiences on greywater re-use for toilet flushing in a hotel (Mallorca Island, Spain). Desalination, 164, pp. 241-247, 2004.

[8] Mayer, P.W., DeOreo, W.B., Opitz, E.M., Kiefer, J.C., Davis, W.Y., Dziegielewski, B. \& Nelson, J.O., Residential End Uses of Water, AWWA Research Foundation and American Water Works Association: Denver, CO, 1999.

[9] Nolde, E., Greywater reuse systems for toilet flushing in multi-storey buildings - over ten years experience in Berlin. Urban Water, 1, pp. 275-284, 1999.

[10] Foster, S.S.D. \& Chilton, P.J., Downstream of downtown: urban wastewater as groundwater recharge. Hydrogeology Journal, 12, pp. 115-120, 2004. 
[11] Gikas, P. \& Tchobanoglous, G., The role of satellite and decentralized strategies in water resources management. Journal of Environmental Management, 90, pp. 144$152,2009$.

[12] Lu, W. \& Leung, A.Y.T., A preliminary study on potential of developing shower/laundry wastewater reclamation and reuse system. Chemosphere, 52, pp. 1451-1459, 2003.

[13] Alqam, M., Jamrah, A., Abd Al-Hafith, B., Al-Zubi, R. \& Al-Shamari, N., Fresh and hardened properties of sustainable concrete using recycled household greywater. Arabian Journal for Science and Engineering, 39, pp. 1701-1708, 2014.

[14] Asadollahfardi, G., Delnavaz, M., Rashnoiee, V. \& Ghonabadi, N., Use of treated domestic wastewater before chlorination to produce and cure concrete. Construction and Building Materials, 105, pp. 253-261, 2016.

[15] COP, Code of Practice for Reuse of Greywater in Western Australia 2010, Department of Health, Government of Western Australia, 2010.

[16] Eriksson, E., Auffarth, K., Henze, M. \& Ledin, A., Characteristics of grey wastewater. Urban Water, 4, pp. 85-104, 2002.

[17] WHO-ROEM, Overview of Graywater Management: Health Considerations, World Health Organization, Regional Office for the Eastern Mediterranean, Centre For Environmental Health Activities: Amman, Jordan, 2006.

[18] Chaillou, K., Gérente, C., Andrès, Y. \& Wolbert, D., Bathroom greywater characterization and potential treatments for reuse. Water, Air, \& Soil Pollution, 215, pp. 31-42, 2011.

[19] Zeeman, G., Fayyed, M., van Lier, J. \& Abu-Ghunmi, L.N.A.H., Quantitative and qualitative characteristics of grey water for reuse requirements and treatment alternatives: the case of Jordan. Water Science and Technology, 58, pp. 1385-1396, 2008.

[20] Jokerst, A., Sharvelle, S.E., Hollowed, M.E. \& Roesner, L.A., Seasonal performance of an outdoor constructed wetland for graywater treatment in a temperate climate. Water Environment Research, 83, pp. 2187-2198, 2011.

[21] Santasmasas, C., Rovira, M., Clarens, F. \& Valderrama, C., Grey water reclamation by decentralized MBR prototype. Resources, Conservation and Recycling, pp. 102107, 2013.

[22] Morel, A. \& Diener, S., Grey Water Management in Low and Middle-Income Countries. Water and Sanitation in Developing Countries (Sandec), Swiss Federal Institute of Aquatic Science and Technology: Eawag, Switzerland, 2006.

[23] Friedler, E. \& Hadari, M., Economic feasibility of on-site greywater reuse in multistorey buildings. Desalination, 190, pp. 221-234, 2006.

[24] City of Los Angeles, Graywater pilot Project Final Report, Office of Water Reclamation: Los Angeles, CA, 1992.

[25] Imteaz, M. \& Shanableh, A., Feasibility of recycling grey-water in multi-storey buildings in Melbourne, 2nd World Sustainability Forum, 2011.

[26] Mandal, D., Labhasetwar, P., Dhone, S., Dubey, A.S., Shinde, G. \& Wate, S., Water conservation due to greywater treatment and reuse in urban setting with specific context to developing countries. Resources, Conservation and Recycling, 55, pp. 356361, 2011.

[27] Judd, S. \& Judd, C., The MBR Book (2nd ed.), Butterworth-Heinemann: Oxford, pp. 1-54, 2011.

[28] Surendran, S. \& Wheatley, A.D., Grey-water reclamation for non-potable re-use. Water and Environment Journal, 12, pp. 406-413, 1998. 
[29] Godfrey, S., Labhasetwar, P. \& Wate, S., Greywater reuse in residential schools in Madhya Pradesh, India-A case study of cost-benefit analysis. Resources, Conservation and Recycling, 53, pp. 287-293, 2009.

[30] Mourad, K.A., Berndtsson, J.C. \& Berndtsson, R., Potential fresh water saving using greywater in toilet flushing in Syria. Journal of Environmental Management, 92, pp. 2447-2453, 2011.

[31] Couto, E. de A. do, Calijuri, M.L., Assemany, P.P., Santiago, A. da F. \& Lopes, L.S., Greywater treatment in airports using anaerobic filter followed by UV disinfection: an efficient and low-cost alternative. Journal of Cleaner Production, 106, pp. 372-379, 2015.

[32] MoEW, National Water Sector Strategy, Lebanese Government: Beirut, 2012.

[33] Constantine, K., Massoud, M., Alameddine, I. \& El-Fadel, M., The role of the water tankers market in water stressed semi-arid urban areas: Implications on water quality and economic burden. Journal of Environmental Management, 188, pp. 85-94, 2017. 